\title{
Erratum to: A neural marker of medical visual expertise: implications for training
}

\author{
Liam Rourke $^{1}$ (D) $\cdot$ Leanna C. Cruikshank ${ }^{1} \cdot$ Larissa Shapke $^{1} \cdot$ \\ Anthony Singhal ${ }^{2}$
}

Published online: 10 November 2016

(C) Springer Science+Business Media Dordrecht 2016

\section{Erratum to: Adv in Health Sci Educ \\ DOI 10.1007/s10459-016-9712-7}

In the original online publication, the name of author Leanna C. Cruikshank was incorrectly given as Leanna Cruickshank. The original publication has now been corrected as well.

The online version of the original article can be found under doi:10.1007/s10459-016-9712-7.

\section{Liam Rourke}

1rourke@ualberta.ca

1 Department of Medicine, University of Alberta, Edmonton, Canada

2 Department of Psychology, University of Alberta, Edmonton, Canada 